Pamiętnik Literacki 2019, 3, s. 161-182

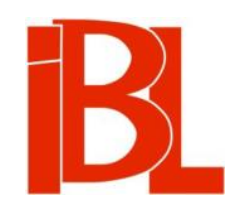

\title{
Wojna, emigracja i dusza poety. $O$ korespondencji Hermanna Brocha i Józefa Wittlina
}

\author{
Agnieszka Hudzik
}


Pamiętnik Literacki CX, 2019, z. 3, PL ISSN 0031-0514

DOI: $18318 /$ PL.2019.3.11

AGNIESZKA HUDZIK Universität Potsdam

\section{WOJNA, EMIGRACJA I DUSZA POETY O KORESPONDENCJI HERMANNA BROCHA I JÓZEFA WITTLINA*}

To mógł być gorący dzień na przełomie czerwca i lipca 1945. Nowy Jork, akcja dzieje się najprawdopodobniej w siedzibie nowo powołanego American Committee for Emigré Scholars, Writers and Artists. Instytucja to niezwykle prestiżowa. Wystarczy wspomnieć, że do jej zarządu należeli m.in. Marion Canby - poetka zaangażowana w pomoc intelektualistom, którzy uciekli z Europy, ekonomistka Else Staudinger, pełniąca funkcję sekretarza komitetu, czy Alvin S. Johnson, założyciel New School for Social Research ${ }^{1}$. Wiele oficjalnych pism komitetu zostało zdigitalizowanych i łatwo odnaleźć je dziś w Internecie, na papierze firmowym widnieje adres: „66 Fifth Avenue, siódme piętro”. To nieopodal parku Union Square w samym centrum Manhattanu, prawdopodobnie mieściła się tam wynajęta powierzchnia biurowa albo mieszkanie jednego $\mathrm{z}$ członków zarządu. Owego dnia w wysokim wieżowcu zapewne było dość duszno, zwłaszcza po południu, kiedy to przypuszczalnie zwołano zebranie plenarne komitetu, ostatnie przed przerwą wakacyjną. Niewykluczone, że było to nieformalne spotkanie przy kawie i ciastkach, zorganizowane w celu wymiany opinii i budowania sieci kontaktów. Mogło ono wyglądać następująco:

Pani Canby i pani Staudinger witaja gości w korytarzu. W pokojach jest już tłoczno, przyszło wielu artystów, pisarzy i naukowców, przybyły także znane osobistości zajmujące się publicystyką albo związane $\mathrm{z}$ rozmaitymi fundacjami. W tłumie słychać język angielski i niemiecki. Najczęstszym tematem rozmów są aktualne wiadomości o niepewnej sytuacji w Europie tuż po zakończeniu wojny. To trudny czas, jeszcze przed konferencją poczdamska, trwa wytyczanie nowych

* Artykuł stanowi polska, znacznie przepracowaną i rozszerzoną wersję tekstu w jezzyku niemieckim Krieg, Exil und die Seele des Dichters: Hermann Broch und Józef Wittlin im Briefwechsel przeznaczonego do „Przeglądu Humanistycznego” (2019, nr 1 〈w druku〉). Oba teksty powstały dzięki pobytowi badawczemu w Beinecke Rare Book \& Manuscript Library (Uniwersytet Yale, New Haven) w ramach stypendium Visiting Research Scholar Fellowship. Autorka dziękuje za uprzejmą zgodę na publikację fotografii archiwom: Beinecke Rare Book \& Manuscript Library (il. 1) oraz Houghton Library (il. 2-5).

1 Uczelnia założona w r. 1919, od 1933 r. stała się siedzibą Uniwersytetu na Uchodźstwie (University in Exile), powstałego z myślą o pomocy europejskim uczonym i intelektualistom, którym życie i kariery zawodowe zniszczył reżym hitlerowski. W roku 1934 Uniwersytet przekształcił się w wydział w New School - Graduate Faculty of Political and Social Science. 
granic i demilitaryzacja. Wszyscy, zatroskani i przejęci, dyskutują o tym, co się dzieje za oceanem. Nagle słychać głośne pukanie do drzwi. Wchodzi Józef Wittlin z żoną Haliną. Są nieco spóźnieni, mieszkają w okolicach Nowego Jorku i mieli do przebycia długą drogę na Manhattan. Wita ich pani Staudinger, po niemiecku pyta o zdrowie, plany na lato i postepy w pracy twórczej. Wittlin otrzymuje od komitetu niewielkie stypendium oraz drobne zlecenia pisarskie. Wymieniają kilka kurtuazyjnych zwrotów, nagle pani Staudinger klaszcze głośno w dłonie i stwierdza, że koniecznie musi Wittlina z kimś zapoznać: „To również literat, bardzo sławny. Prawdopodobnie już Pan o nim słyszał, właśnie ukazało się jego najnowsze dzieło". Mówiąc to, prowadzi go do stołu, przy którym siedzi Hermann Broch. Nie jest sam, wokół niego gromadzą się ludzie. Każdy chce zajrzeć do dwóch egzemplarzy książek, które, przekazywane z rąk do rąk, krążą po pokoju: Der Tod des Vergil i The Death of Vergil. Wittlin przedstawia się krótko i gratuluje Brochowi wydania w dwóch językach równocześnie. Stara się rozpocząc ciekawą rozmowę i pyta z zakłopotaniem: „Czy to biografia Wergilego?”

To niezręczne, nieco banalne zdanie będzie jeszcze długo męczyć Wittlina. Jako wielki znawca literatury starożytnej i tłumacz Odysei Homera na język polski jest, oczywiście, zaintrygowany tytułem publikacji. Wkrótce udaje mu się ją wypożyczyć, $n b$. od kuzyna niejakiego Ericha von Kahlera, filozofa kultury i literaturoznawcy, u którego przez długi czas mieszkał gościnnie Broch. W pierwszej edycji Śmierci Wergilego, która ukazała się w słynnym wydawnictwie „Pantheon Books”, założonym przez Helen i Kurta Wolffów, celowo nie zamieszczono na okładce tradycyjnego podtytułu, sygnalizującego gatunek literacki ${ }^{2}$. W trakcie czytania Wittlin zdaje sobie sprawę, jak hybrydowy jest to utwór. Tekst łączy w sobie różne formy: powieść, poezję, esej filozoficzny i dialog dramatyczny. Zafascynowany tym Wittlin czuje potrzebę skontaktowania się z Brochem i przeproszenia go za tamten niefortunny początek rozmowy. Udaje mu się zdobyć adres. Pod koniec lipca 1945 pisze pierwszy list, a na odpowiedź czeka tylko trzy dni.

$\mathrm{W}$ ten sposób rozpoczyna się, dotychczas nie opublikowana, korespondencja, która trwa aż do śmierci Brocha w 1951 roku. W niniejszym tekście chcę zrekonstruować poruszane w niej tematy, dotyczace emigracji, procesu twórczego, problemów literatury i sztuki. Listy znajdują się obecnie w dwóch archiwach, w Beinecke Rare Book \& Manuscript Library oraz w Houghton Library. Pozostaja, jak dotąd, nieosiagalne dla polsko- i niemieckojęzycznych literaturoznawców - twórczość obu pisarzy przyporzadkowuje się bowiem do odrębnych kręgów kulturowych i, co za tym idzie, do oddzielnych pól badawczych. Artykuł stawia sobie za cel próbe wypełnienia tej białej plamy w biograficzno-historycznym obrazie obydwu kręgów literackich i przerzucenia między nimi pomostu.

\section{Korespondencje między życiorysami i między utworami}

Niezależnie od wymiany listów - biografie i twórczość Brocha i Wittlina łączy wiele punktów wspólnych. Obaj byli w pewnym sensie rodakami: urodzili się w imperium

2 J. Heizmann, Der Tod des Vergil. W zb.: Hermann-Broch-Handbuch. Hrsg. M. Kess s er, P. M. Lützeler. Berlin-Boston 2016, s. 170. 
habsburskim. Zostali też ukształtowani przez podobne doświadczenia, takie jak pierwsza wojna światowa, studia w Wiedniu, żydowskie pochodzenie, prześladowanie ze strony nazistów czy w końcu ucieczka do Stanów Zjednoczonych.

Józef Wittlin (1896-1976) urodził się w galicyjskim Dmytrowie, młodość zaś spędził we Lwowie. Tam też miał krótki epizod militarny: jeszcze przed ukończeniem szkoły, gdy wybuchła wojna, zgłosił się na ochotnika do służby w Legionie Wschodnim. Ten jednak po krótkim czasie został rozwiązany, ponieważ część legionistów odmówiła złożenia przysięgi na wierność cesarzowi austriackiemu. Kiedy armia rosyjska zbliżała się do Lwowa, Wittlin uciekł do Wiednia, gdzie w 1915 r. zdał maturę i podjął studia. Karierę literacką rozpoczął jako poeta - w 1920 r. ogłosił tom Hymny - oraz jako tłumacz ${ }^{3}$. Przełom w jego twórczości nastapił w r. 1935 wraz z publikacją Soli ziemi; powieść szybko została przetłumaczona na wiele języków, a jej autor był nawet brany pod uwagę jako kandydat do literackiej Nagrody Nobla.

W lipcu 1939 Wittlin opuścił Polskę, następnie przez Francję i Portugalię uciekł do Nowego Jorku, gdzie mieszkał od 1941 r. aż do śmierci. Na emigracji publikował głównie artykuły i eseje, w większości zebrane w obszernym tomie Orfeusz w piekle XX wieku. Książkę tę otwiera tekst Wojna, pokój i dusza poety, gdzie mowa jest o tragizmie ludzi pióra, którzy w trakcie Wielkiej Wojny stali się trybikami morderczej maszyny i do końca życia nie mogą się wyrwać $z$ „bolesnego zadumania” 4 .

To zdanie można by też odnieść do losu Hermanna Brocha (1886-1951). On również w połowie 1915 r. dobrowolnie zgłosił się do służby wojskowej w cesarsko-królewskim Pułku Ułanów nr 12. „Najwyraźniej dla pozoru” - jak twierdzą biografowie pisarza, chociaż także $z$ powodu presji patriotycznie nastawionej rodziny, zwłaszcza ze strony ojca, szanowanego producenta tekstyliów i zasymilowanego Żyda ${ }^{5}$. Broch otrzymał jednak oficjalną odmowę - jako przyczynę podano to, iż przekroczył wymagana granicę wieku, oraz fakt, że już wcześniej został uznany za niezdolnego do służby. W zamian mianowano go dyrektorem lazaretu Czerwonego Krzyża dla lekko rannych, który znajdował się na terenie jego fabryki w pobliżu Wiednia. Szpital wojskowy i przebywający w nim pacjenci - tacy jak np. podporucznik po amputacji ręki w wyniku użycia gazu trującego - stał się ważnym miejscem akcji w trylogii Lunatycy (1930-1932), która stanowiła dość późny debiut literacki Brocha. Po nim publikował on kolejne powieści, jak również sztuki teatralne, poezje, eseje i pisma teoretyczne. W roku 1939 Broch uciekł przez Londyn do Stanów Zjednoczonych, gdzie spędził resztę swego życia. Na emigracji stworzył m.in. Śmierć Wergilego - monumentalną powieść o ostatnich godzinach umierającego rzymskiego poety, często porównywaną do dzieł Jamesa Joyce’a i Thomasa Manna.

3 Wittlin przełożył na polski wiele tekstów literackich, zwłaszcza lirykę $\mathrm{z}$ kilku języków - z włoskiego (wiersze takich autorów, jak U. Saba, S. Quasimodo czy A. Gatto), z hiszpańskiego (C. Bousoño, J. L. Cano, M. Hernández), z niemieckiego (H. Kesten) i z angielskiego (R. Jeffers, L. Hughes, W. C. Williams, W. H. Auden). Jego przekłady zebrane są w antologii Przyjaźnie poetyckie Józefa Wittlina (Oprac., posł. Z. K u b i a k. Warszawa 1995). Ponadto z dorobku translatorskiego Wittlina należy wspomnieć utwory R. Dehmela, R. M. Rilkego, powieść Wilk stepowy H. Hessego i dzieła J. Rotha, o czym jeszcze będzie mowa dalej.

4 J. Wittlin, Orfeusz $w$ piekle XX wieku. Posł. J. Zi elińs ki. Kraków 2000, s. 31.

5 P. M. Lützele r, Hermann Broch. Eine Biographie. Frankfurt am Main 1985, s. 61. 
W roku 1951 stowarzyszenia literackie i przyjaciele Brocha próbowali zgłosić jego kandydaturę do literackiej Nagrody Nobla. Plany te zniweczyła, niestety, śmierć pisarza.

Zbieżności między Brochem a Wittlinem są także widoczne w ich utworach, zwłaszcza w powieściach, podejmujących temat pierwszej wojny światowej. Bohater Soli ziemi to Piotr Niewiadomski - pół-Hucuł, człowiek naiwny i łatwowierny, prostaczek, analfabeta, kolejarz, mieszkający we wsi u podnóża Karpat. Wybuch wojny jest dla niego szokiem, burzy jego dotychczasowe życie: „Słowo: wojna - jak ciężka gruda trzasnęło go w głowę. Przebiło czaszkę, przebiło opony i wdarło się do mózgu"6. Wkrótce Niewiadomski zostaje wcielony do wojska; powieść relacjonuje jego przygody, które rozgrywają się między lipcem a sierpniem 1914, i ma wydźwięk jednoznacznie pacyfistyczny. W entuzjastycznej recenzji Alfred Döblin porównał bohatera Wittlina do Haškowskiego dobrego wojaka Szwejka ${ }^{7}$. Obecnie opinię tę podziela Martin Pollack, w posłowiu do najnowszego wydania Soli ziemi w języku niemieckim dodając, że tak naprawdę nie jest to książka o wojnie, tylko o człowieku, którego najpierw trzeba do niej uformować, zanim wbije się go w mundur i wypastowane kamasze, napełni ślepym posłuszeństwem, a następnie wyśle na front ${ }^{8}$.

Podczas gdy Niewiadomski uosabia początkowy etap transformacji cywila w żołnierza, Huguenau z trzeciego tomu trylogii Brocha Lunatycy zdaje się symbolizować końcową fazę tego procesu. 1918 Huguenau, czyli rzeczowość - to pełne brzmienie tytułu ostatniej części powieści, która składa się z różnych wątków narracyjnych, tworzących wielowarstwowa pesymistyczną diagnozę tamtych czasów. Traktuje ona o kryzysie kultury zachodniej i rozpadzie starych systemów wartości. Jak wiadomo, sa to słowa-klucze ówczesnego dyskursu humanistycznego w Niemczech. Oswald Spengler w pierwszym tomie swojego Zmierzchu Zachodu (1918) pisze o ostatnim „duchowym kryzysie”, przed którym stoi cywilizacja europejska, jako o areligijnej wersji mitu o „końcu świata” i „zmierzchu bożyszcz” (tu oczywiście aluzja do Friedricha Nietzschego). Spengler wiązał ten kryzys z „tyranią rozumu”, której najsilniejszym wyrazem miał być „kult nauk ścisłych, dialektyki, dowodzenia, doświadczenia i przyczynowości”’.

Wróćmy do powieści. Huguenau to kupiec z Alzacji, ma około 30 lat, zostaje powołany do wojska, a następnie wysłany na front, skąd dezerteruje w roku 1918. W trakcie ucieczki przybywa do miasteczka w bocznej dolinie rzeki Mozeli. Tam bez skrupułów i bez skruchy dopuszcza się okrucieństw: gwałtu oraz morderstwa. Jest całkowicie pozbawiony sumienia - świat spoczywa przed nim „szary, zrobaczywiały i całkiem martwy w niezłomnym milczeniu" ${ }^{10}$. Ani nim, ani rzeczywistością, która go otacza, nie rządzą żadne prawa - ni to dialektyki, jakiejś konieczności dziejowej, ni to przyczynowości; zbrodnie te były absurdalne, pozbawione jakich-

6 J. Wit tli in, Sól ziemi. Oprac. E. Wi e ga n d t. Wrocław 1991. BN I 278, s. 40.

7 A. Döblin, Polski wojak Szwejk. O powieści „Sól ziemi” Józefa Wittlina. Przeł. M. A. Noga. „Konteksty Kultury” 2017, z. 2.

8 M. P oll a c k, Ein Charlie Chaplin des Ersten Weltkriegs. W: J. W it t l i n, Das Salz der Erde. Übers. I. B erm a n, M. S e eger. Frankfurt am Main 2014, s. 265.

9 O. S pengl er, Zmierzch Zachodu. Zarys morfologii historii powszechnej. Wybór, oprac., przypisy H. Werner. Przeł. J. Mar zę cki. Warszawa 2014, s. 607-608.

10 H. Broch, Lunatycy. Przeł. S. Bła u t. Posł. Z. J. Lich há ski. Wyd. 2. Wrocław 2005, s. 285. 
kolwiek powodów i następstw w postaci kary lub nagrody czy korzyści. Morderca z czasem zapomina więc o swych czynach, staje się poważanym mieszczaninem, człowiekiem interesu, uczciwym obywatelem i ojcem rodziny. Swoją osobą ucieleśnia „absolutny punkt zerowy historii” ${ }^{11}$. Badacze literatury zwykli go nawet określać mianem „radosnego nihilisty”, który w swojej banalności ma przypominać Nietzscheańskiego „ostatniego człowieka” ${ }^{12}$.

Warto podkreślić, że Wittlin przez całe życie pracował nad dwoma kolejnymi tomami Soli ziemi. Od samego początku planował bowiem napisać trylogię - co nb. zaraz uruchamia skojarzenie $z$ Lunatykami Brocha - i nadać jej tytuł Powieść o cierpliwym piechurze. Kolejnym podobieństwem w twórczości obu autorów jest ich silne zainteresowanie mitami i motywami antycznymi, wyraźnie występujące m.in. w powieści Śmierć Wergilego i w zbiorze esejów Orfeusz w piekle XX wieku. Ciekawym zagadnieniem badawczym byłoby prześledzenie, jakie istnieją pomiędzy tymi tekstami zbieżności w zakresie nawiązań do starożytności oraz refleksji nad wygnaniem i emigracją. Oprócz analogicznych tematów w prozie - Brocha i Wittlina łączy szczególna pasja do listów. Dla obu korespondencja była ważną forma pisarstwa i stanowiła integralną część ich pracy literackiej.

\section{Maniakalni epistolografowie}

Zarówno Broch, jak i Wittlin z upodobaniem pisali listy, często równocześnie prowadzili ożywioną korespondencję $z$ wieloma znaczącymi osobami.

Jak dotąd, wydano kilka tomów spuścizny epistolarnej Wittlina: Listy, wymieniane m.in. ze Stefanem Żeromskim i Julianem Tuwimem ${ }^{13}$, ponadto, jako osobne publikacje, korespondencję $\mathrm{z}$ Witoldem Gombrowiczem ${ }^{14}$ oraz z Jerzym Giedroyciem $^{15}$. Redaktor naczelny paryskiej „Kultury” intensywnie motywował swojego adresata do pracy twórczej - w „Kulturze” opublikował on w sumie 16 artykułów. Ich kontakty listowne trwały prawie 30 lat i obejmują aż 479 wiadomości: 256 od Wittlina, 223 od Giedroycia. Znajdująca się w archiwach, nie wydana wcześniej korespondencja Wittlina np. z Czesławem Miłoszem czy z Romanem Brandstaetterem ostatnio została już szczegółowo opracowana i omówiona przez badaczy ${ }^{16}$. Nie można tego natomiast powiedzieć o jego listach pisanych w języku niemieckim.

Niedawno zbiory epistolarne Wittlina stały się nawet tematem filmu ekspery-

S. D. D ow d e n, Die Schlafwandler. W zb.: Hermann-Broch-Handbuch, s. 99. Ibidem, s. 100.

J. Wittlin, Listy. Oprac. T. Januszews ki. Warszawa 1996.

W. Gombrowicz, J. Wittlin, J. Iwaszkiewicz, A. Sandauer, Gombrowicz-walka o sławę. Korespondencja. Cz. 1. Układ, przedm., przypisy J. J a r zęb s ki. Kraków 1996. Wittlin odegrał ważną rolę w rozwoju kariery literackiej Gombrowicza za granica, m.in. w 1951 r. napisał dla „Kultury” tekst Apologia Gombrowicza.

J. Giedroy c, J. Wittlin, Listy 1947-1976. Oprac., wstęp, przypisy R. Habielski, P. Kądzi ela. Warszawa 2017.

Zob. R. Zaj ą c z k ow s k i: Korespondencja między Józefem Wittlinem i Romanem Brandstaetterem. „Tematy i Konteksty” nr 2 (2012); Pamiętnik wygnańca. Z nieznanej korespondencji Józefa Wittlina. „Ruch Literacki” 2014, nr 4/5; Listy Józefa Wittlina do Czesława Miłosza. „Pamiętnik Literacki” 2017, z. 1 . 
mentalnego MS Slavic $7 \mathrm{w}$ reżyserii Sofii Bohdanowicz i Deragh Campbell, prezentowanego na tegorocznym festiwalu Berlinale w sekcji „Forum” ${ }^{17}$. Tytuł filmu to sygnatura biblioteczna, którą oznaczona jest korespondencja Wittlina przechowywana w Houghton Library (również ta $z$ Brochem). Osią fabuły są listy wymieniane w latach 1957-1964 między Wittlinem a polską poetką Zofią Bohdanowiczową, żyjącą również na emigracji - w Kanadzie.

Można zauważyć, że kontakty listowne Wittlina intensyfikują się na emigracji. Niektórzy badacze tłumaczą to tym, iż sztuka epistolarna stała się dla niego rodzajem bądź ucieczki przed kryzysem twórczym, bądź remedium przeciw obsesyjnemu perfekcjonizmowi i niespełnieniu artystycznemu. Podobno w Nowym Świecie autor Soli ziemi miał problemy z koncentracja, jakiej wymaga beletrystyka ${ }^{18}$.

Podobnym zagorzałym epistolografem był Broch. Pisanie listów stanowiło dla niego pasję i ważny środek komunikacji. Paul Michael Lützeler, jego biograf, mówi nawet otwarcie o „obsesji na punkcie korespondencji” ${ }^{19}$ i dla zobrazowania nadpobudliwości epistolarnej pisarza rekonstruuje kilka danych statystycznych: chociażby w 1946 r. w przeciagu 16 dni Broch wysłał 123 wiadomości i pisał około 30 do 40 stronic samych listów dziennie ${ }^{20}$. Nic dziwnego, że wydanie krytyczne jego dzieł zebranych pod redakcją Lützelera obejmuje aż 3 tomy korespondencji, zawierające prawie 800 listów. Przedstawiają one zaledwie część obszernej epistolografii - w tym wyborze nie został uwzględniony Wittlin. Ponadto w osobnych tomach zaopatrzonych w komentarz i rozbudowany aparat krytyczny wydano wymianę listów Brocha z takimi osobami, jak Hannah Arendt, Hans Günther Adler, Ruth Norden, Frank Thiess, Egon Vietta czy Annemarie Meier-Graefe, druga żona Brocha ${ }^{21}$.

\section{Listy}

Mimo iż korespondencje prowadzone przez Brocha i przez Wittlina poddano wnikliwym badaniom, rzadko szuka się powiązań między obu twórcami. W literaturze przedmiotu występuje jedynie niewiele wzmianek o ich kontaktach ${ }^{22}$. Nic dziwnego, ad hoc przyporządkowuje się ich raczej różnym kręgom kulturowym - polskim albo

Zob. wywiad A. Cooka z S. Bohdanowicz i D. Campbell, Ein Brief ist ein Monolog, in dem man sein eloquentestes Selbst präsentiert [List jest monologiem, w którym prezentuje się swoje najbardziej elokwentne ,ja”]. Na stronie: https://www.arsenal-berlin.de/berlinale-forum/ programm-forum/hauptprogramm/ms-slavic-7.html (data dostępu: 1 VIII 2019).

Zob. T. Januszewski, wstęp w: J. Wittlin, Listy. Oprac. T. Jan u szewski. Warszawa 1996, s. 7.

19 P. M. Lützeler, Nachwort des Herausgebers. W: H. Broch, Kommentierte Werkausgabe. Hrsg. P. M. Lützele r. T. 13. Cz. 3: Briefe 3 (1945-1951). Frankfurt am Main 1994, s. 625.

20 P. M. Lützele r, Hermann Broch. Eine Biographie, s. 308.

21 O Brochu jako epistolografie zob. G. B artra m, Brochs epistolarisches Werk. W zb.: Hermann-Broch-Handbuch. - S. P. S c h e i c hl, Hermann Broch als Briefschreiber. W zb.: Hermann Broch. Modernismus, Kulturkrise und Hitlerzeit. Hrsg. A. Stevens, F. Wagner, S. P. Scheichl. Innsbruck 1994.

22 O ich wymianie listów wspomina w swoim artykule slawista A. Law aty, przy czym omawia jedynie listy Brocha do Wittlina (Wittlin and German Literature. Friends in an Unfriendly World. W zb.: Between Lvov, New York, and Ulysses' Ithaca. Józef Wittlin: Poet, Essayist, Novelist. Ed. A. Frajlich. Torun - New York 2001, s. 149. 
niemieckojęzycznym środowiskom emigracyjnym, chociaż w rzeczywistości były one silnie ze soba powiązane. Poza tym Wittlin kojarzony jest przede wszystkim z Josephem Rothem ${ }^{23}$. W czasie długich lat ich przyjaźni pisarze ci niejednokrotnie wzajemnie się wspierali oraz inspirowali w działalności literackiej. Wittlin przetłumaczył 5 powieści Rotha - m.in. Hioba i Ucieczkę bez kresu ${ }^{24}$. Dzięki wsparciu Rotha natomiast w 1937 r. w Amsterdamie wydano pierwsze niemieckie tłumaczenie Soli ziemi ${ }^{25}$. Druga, poprawiona edycja ukazała się w 1969 roku. Dwa lata później Wittlin został przyjęty do Niemieckiej Akademii Języka i Literatury. W przemówieniu przygotowanym na tę okazję pisarz zastanawiał się nad różnymi aspektami emigracji i uchodźstwa - według niego każdą twórczość można rozpatrywać jako wygnanie: ucieczkę od rzeczywistości i od konformizmu. Status wygnańca miałby być poniekąd „stanem pierwotnym” artysty ${ }^{26}$. Wyjaśniał też Wittlin, skąd tak doskonale zna niemiecki. Był to jego ,język macoszy” (Stiefmuttersprache; gra słów: po niemiecku język ojczysty to Muttersprache, macocha zaś - Stiefmutter); po śmierci matki Wittlina bowiem jego ojciec ożenił się po raz drugi z Niemką, aktorką, dzięki czemu przyszły pisarz wyrósł niemal na monologach z dramatów Friedricha Schillera.

Broch natomiast miał raczej niewiele bezpośrednich powiązań ze słowiańskim obszarem kulturowym, chociaż bardzo się nim interesował. W liście do swojego czeskiego tłumacza, Paula Eisnera, z 11 VI 1946, przyznaje, że w młodości przebywał przez rok w miejscowości Dvưr Králové nad Labem i uczył się czeskiego, ale bez większego powodzenia. Nawet tę odrobinę, którą zdołał sobie przyswoić, zaraz zapomniał. Brak znajomości języków słowiańskich bardzo miał mu doskwierać $\mathrm{w}$ trakcie jego pracy nad artykułem o przekładzie ${ }^{27}$. Również w korespondencji z Wittlinem wykazuje Broch żywe zainteresowanie językiem i literatura polską. Wittlin opowiada mu np. w liście z 22 XII 1948 o współredagowaniu tomu o Adamie Mickiewiczu ${ }^{28}$ i zaprasza do udziału. W odpowiedzi Broch przyznaje, że polskiego romantyka kojarzy jedynie $z$ nazwiska, żadnych jego dzieł nie czytał i że odczuwa z tego powodu „metafizyczne cierpienie kolekcjonera znaczków, który nie może

23 Poznali się oni w 1915 r. na wykładach germanisty W. Brechta na Uniwersytecie Wiedeńskim, gdzie obaj studiowali filozofię. Roth pochodził ze wschodniogalicyjskiego miasta Brody i mówił także po polsku. Już przy pierwszym spotkaniu Wittlin zwrócił na niego uwage - opisuje go jako rzucającego się w oczy, typowego „Wiener Gigerl [wiedeńskiego strojnisia]”: elegancko ubranego, szczupłego, Z monoklem i przedziałkiem na środku. Zob. J. W it tl i n, Wittlin Meets Roth. (Book Review). „Books Abroad” 1944, z. 4, s. 342.

24 J. Roth: Hiob. Powieść o człowieku prostym. Przeł. J. Wittli n. Warszawa 1931; Ucieczka bez kresu. Przeł. J. Wittlin. Warszawa 1931.

25 Zob. J. Rze pa, „Sól ziemi” Józefa Wittlina. W kręgu recepcji „pozapolskiej” powieści. „Przekładaniec” nr 27 (2013). - M. Ri etr a, Joseph Roth und Józef Wittlin. Zur Entstehung der deutschen Übersetzung „Das Salz der Erde” und deren Bedeutung für den Erfolg von Wittlins Roman „Sól ziemi”. „Neophilologus” 2017, nr 1.

26 J. Wittli n, Przemówienie z okazji wyboru do Niemieckiej Akademii Literatury. W: Eseje rozproszone. Oprac. P. Ką dziela. Warszawa 1995, s. 163.

27 Chodzi o wykład H. B r o c h a Einige Bemerkungen zur Philosophie und Technik des Übersetzens (1946), zamieszczony w Kommentierte Werkausgabe (t. 9, cz. 2: Schriften zur Literatur/Theorie).

28 Mowa o tomie zbiorowym Adam Mickiewicz - Poet of Poland. A Symposium. Ed. M. Krid1, with forew. by E. J. Sim mons. New York 1951. 
znieść myśli, że musi umrzeć, zanim całkowicie nie skompletuje swojej kolekcji” (21 X 1948). Nie przyjmuje propozycji napisania tekstu do książki, ale w liście obiecuje uzupełnić „luki w swojej edukacji” (1 I 1949).

Do dziś nie publikowana korespondencja omawianych pisarzy przebiegała w latach 1945-1951 i prowadzona była, oczywiście, w języku niemieckim, z wyjątkiem kilku krótszych wiadomości czy wstawek po angielsku. Ich listy przechowywane są w dwóch różnych archiwach literatury. Listy Wittlina znajdują się w Beinecke Rare Book \& Manuscript Library na Uniwersytecie Yale w New Haven, w spuściźnie Hermanna Brocha (sygn. YCGL MSS 1, Box 15/440). Zachowało się w sumie 8 listów, $6 \mathrm{z}$ nich to manuskrypty; średnia długość listu to około jednej stronicy formatu A4. Odpowiedzi Brocha można natomiast znaleźć w kolekcji dokumentów dotyczącej Józefa Wittlina mieszczącej się w Houghton Library, jednej $z$ bibliotek uniwersyteckich na Harvardzie w Cambridge w Massachusetts (sygn. MS Slavic $7\langle 29\rangle$ ). Zbiór ten obejmuje 24 listy, w większości są one pisane na maszynie, wśród nich znajduje się kilka odręcznych pocztówek, niektóre z nich w języku angielskim.

Obydwaj korespondenci zachowuja formy grzecznościowe, konsekwentnie zwracając się do siebie per „pan”. Najprawdopodobniej spotkali się też kilka razy osobiście i kontaktowali się ze sobą telefonicznie. W samej korespondencji pisarzy, jak i w pozostałych źródłach, takich jak listy do osób trzecich, pojawiają się wyraźne sygnały świadczące o tym, że była ona bardzo żywa i że wiele listów musiało zaginać. Wittlin wspomina o niej, piszac do Gombrowicza ${ }^{29}$. Broch natomiast przesyła listy od Wittlina swojemu przyjacielowi von Kahlerowi do poczytania ${ }^{30}$.

Korespondencje inicjuje Wittlin. W pierwszym liście do Brocha, z 30 VII 1945, posługując się bardzo elegancką i wyrafinowaną niemczyzną, opisuje wspomniane we wstępie do niniejszego artykułu okoliczności, w jakich się poznali. W dniu ukazania się powieści Śmierć Wergilego zostali sobie przedstawieni w trakcie dużego spotkania w Nowym Jorku, które zorganizowały dwie ważne i zasłużone w środowisku emigranckim aktywistki, pośredniczące w nawiązywaniu kontaktów w obrębie rynku wydawniczego i w zakresie mecenatu kultury i sztuki. Wittlin przeprasza Brocha za pytanie, które wówczas spontanicznie zadał, a które obecnie odbiera jako „wyjątkowo płytkie i niesmaczne”. Teraz, po lekturze powieści, zachwycony i poruszony, bardzo ją chwali. Używając nawet nieco egzaltowanych słów, gratuluje serdecznie autorowi znakomitej publikacji; twierdzi, że odkąd ukazały się $W$ poszukiwaniu straconego czasu, Czarodziejska góra oraz powieści Virginii Woolf, nie czytał nic takiego, co by zrobiło na nim aż tak ogromne wrażenie i niemal skłoniło go do odłożenia na bok własnego pisarstwa. Przy okazji prosi Brocha o niemiecki egzemplarz książki - po przecenie - gdyż ten, który miał, był jedynie pożyczony i powinien go niebawem zwrócić właścicielowi.

Broch odpowiada Wittlinowi natychmiast. List z 2 VIII 1945, wysłany z Princeton, rozpoczyna żartobliwie: 


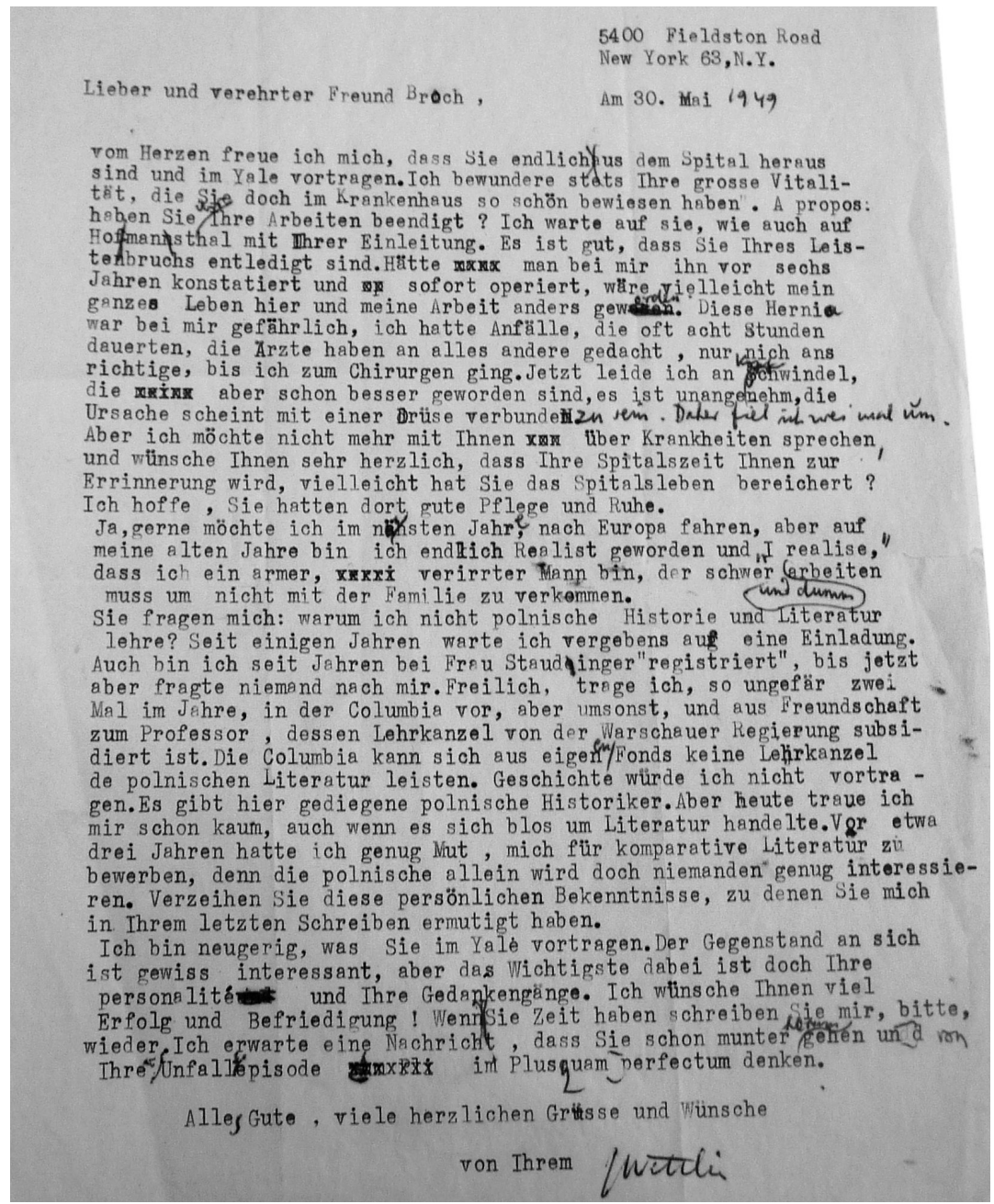

1. Jeden $z$ listów Wittlina do Brocha

Ależ, ależ, drogi panie doktorze Wittlin, jak to być może, że ktoś taki, kto napisał Sól ziemi, pozwala sobie na to, by przez lekturę jakiejś tam książki przeszkadzać sobie we własnym pisaniu!

W kolejnych linijkach Broch opowiada o pracy nad swoją teorią szaleństwa mas i, zaciekawiony, pyta Wittlina o jego tłumaczenie Odysei-jak w polszczyźnie udało mu się oddać heksametr? Obiecuje przesłać egzemplarz Śmierci Wergilego i prosi o przekazanie serdecznych pozdrowień dla żony Wittlina, Haliny.

\section{Powinowactwa duchowe}

Z tonu korespondencji można wnosić o obustronnym uznaniu artystycznym, literaci wydają się w równym stopniu zainteresowani sobą nawzajem. Nie chodzi by- 
najmniej o powierzchowną kurtuazję, nie widać też śladów relacji asymetrycznej, gdzie młodszy kolega po fachu hołdowałby swojemu sławnemu idolowi. Broch postrzega Wittlina jako pisarza, krajana $z$ Europy Środkowej i towarzysza losu, który dzieli z nim trudy życia na emigracji. W liście z 31 VII 1947 autor Lunatyków wskazuje nawet na pewne mentalne podobieństwo i na ten sam etos sztuki, łączące go $\mathrm{z}$ Wittlinem:

Drogi przyjacielu, Panie Wittlinie, widzi Pan, istnieje coś takiego jak wspólnota etycznego radykalizmu. Ja jestem raczej obojętny wobec momentów estetycznych w naszym zawodzie - właściwie to wcale nie chcę być „artystą” - ale w literackiej produkcji wyraźnie wyczuwam ów radykalizm, o który mi (również w mojej własnej pracy) chodzi. I od czasu Pańskiej Soli ziemi wiedziałem, że Pan też jest taki sam.

Wyobrażenie o odpowiedzialności sztuki i o jej zaangażowaniu to kolejny punkt wspólny, który warto byłoby przeanalizować, porównując twórczość obu pisarzy ${ }^{31}$. Także tę, która nie należy do ścisłej beletrystyki: Broch w swoich dziełach politycznych wprowadził pojęcie demokracji totalnej, Wittlin natomiast był współredaktorem antologii Polska myśl demokratyczna w ciagu wieków: „Za wasza i nasza wolność"32, zawierającej teksty oraz dokumenty prezentujące polskie piśmiennictwo polityczne dotyczące demokracji.

Wyczuwalne pokrewieństwo duchowe zachęca obu pisarzy do dzielenia się uwagami o własnych tekstach i o procesie ich powstawania. Broch wielokrotnie wspomina o pracy nad psychologią mas i podkreśla paralele między tym tematem a powieścią o rzymskim poecie. Informuje Wittlina, że jest teraz szczęśliwy, bo w końcu może powrócić do zajmowania się nauka, i dlatego też przypisał swojemu Wergiliuszowi podobne tendencje. W liście z 20 VIII 1945 notuje, że „obie książki jakżeby inaczej - są ściśle ze sobą powiązane, rzec by można, są jedynie irracjonalnym i racjonalnym przedstawieniem w gruncie rzeczy tych samych idei” oraz że dla niego ważnym potwierdzeniem byłoby, gdyby spotkały się z tymi samymi reakcjami. Nawiasem mówiąc, owa autorska wskazówka wydaje się bardzo inspirująca dla badań nad twórczością Brocha. Dotychczas jego teorię szaleństwa mas (w pismach zebranych w tomie Massenwahntheorie) porównywano głównie z powieścią Kusiciel. W niej bowiem pojawia się motyw oczarowania tłumu - zbiorowej ekstazy; wywołuje ją obcy, który przybywa do leżącej w górach wioski i dzięki charyzmie podporządkowuje wiejską społeczność swoim niecnym celom.

Wittlin jest subtelnym komentatorem i wnikliwym czytelnikiem dzieł Brocha. W listach omawia m.in. lekturę jego eseju Mityczne dziedzictwo poezji, który Broch

31 W kontekście dorobku Wittlina J. Jarzęb ski (Konferencja Wittlinowska. W zb.: Etapy Józefa Wittlina. Red. W. Li gę z a, W. S. W o cła w. Kraków 2014, s. 11) używa sformułowania „etyczny projekt literatury": powinna ona przejąć odpowiedzialność za wspólnotę. P. Pija nowski (Pisarza „wrażliwość na cudza krzywdę”. Eseistyka Józefa Wittlina w perspektywie etycznej. W zb.: jw., s. 136) natomiast porównuje „etyczną koncepcję literatury”, którą Wittlin rozwija przede wszystkim w swoich esejach, z teorią kiczu Brocha. Także E. W i e ga nd t (wstęp w: Wi t tli n, Sól ziemi, s. V) pisze o Wittlinowskiej koncepcji zaangażowania etycznego sztuki i podkreśla pojawiającą się u polskiego autora kategorię duszy, ściśle przezeń łączoną z rolą literatury; według niego tylko poezja jest w stanie uratować ludzkość przed utratą uczuć metafizycznych.

32 Tom ukazał się najpierw w języku angielskim w 1944 r. w Londynie i dopiero rok później został wydany po polsku w Nowym Jorku. 
opublikował w specjalnym numerze czasopisma „Neue Rundschau” $z$ okazji siedemdziesiątych urodzin Manna. Mit to pojęcie kluczowe, nie tylko w kontekście przekładania utworów antycznych przez Wittlina, lecz również jako istotny element jego koncepcji poety, rozwijanej w esejach. W korespondencji (list z 30 VII 1945) Wittlin nawiązuje przede wszystkim do powieści Śmierć Wergilego: pisze, że zawsze miał ambiwalentny stosunek do Eneidy, woli od niej Georgiki oraz Bukoliki, podziela więc opinię Brocha, iż spośród rzymskich poetów to Katullus, Tibullus, a także Propercjusz, „którzy spalili się w swoich namiętnościach”, oddziałują dziś „świeżej i prawdziwiej" niż Wergiliusz. W liście z 13 VIII 1945 stwierdza, że powieść Brocha to dla niego „kosmogonia à rebours”, opisująca niemal mityczne zejście do krainy zmarłych:

Sądzę, że udało się Panu wspaniale i po raz pierwszy w literaturze stworzyć nową nekyię. Mianowicie nekyię od środka. Zaświaty w starożytnej i średniowiecznej poezji zawsze były ukazane, że tak powiem, w sposób antropomorficzny, podobnie do zwierząt w bajkach zwierzęcych, które zachowują się i mówią jak ludzie. Zaświaty były postrzegane w kategoriach świata doczesnego [...]. Pańska nekyia rozgrywa się we wnętrzu Wergiliusza i to jest niesamowite. Powieść należy do tych epokowych fenomenów sztuki, które należy oceniać po ich długofalowych oddziaływaniach. Jeśli chodzi o moją skromną osobę, to czuję, jak ta książka coraz silniej zaczyna we mnie żyć - jest jak nowy pokarm dla duszy. Wszystko, co nowe, jest z natury trudne do zrozumienia. Jest to cecha oryginalności. „Rozumie” się tylko to, co znane i co już było. Wierzę jednak, że oprócz inteligencji mamy również inne narządy percepcji, które pozwalają nam wchłaniać nowe zjawiska twórcze, ba - nawet delektować się nimi bez „zrozumienia” wszystkiego. Dlatego uważam, że z pomocą tych oto narządów przeczytałem z zachwytem (i często na głos) drugą i czwartą część Pańskiej powieści. Pierwsza i zwłaszcza tr ze cia część sa już i tak „zrozumiałe”.

Zdaniem Wittlina, Broch w sposób rewolucyjny ukazuje nekyię, czyli topos rozmowy ze zmarłymi po złożeniu im ofiary. Rozważa transcendencję, opowiadając o niej niejako od środka, tworzy jej własną poetykę, przedstawia ją w jej wyjątkowości, zamiast używać do tego znanych schematów narracyjnych czy kategorii świata doczesnego - immanencji. Wittlin zamierzał nawet rozwinąć swoje refleksje o powieści Brocha i napisać dłuższy esej - o tych planach informował Giedroycia w listach $z$ lat siedemdziesiatych ${ }^{33}$ - artykuł jednak nigdy nie powstał.

\section{Nekyia, emigracja i teoria listu}

Termin „nekyia” pojawia się w korespondencji dwukrotnie. Wittlin przywołuje je w liście z 28 VII 1947. Dla obu twórców, znakomitych znawców literatury antycznej, było ono zrozumiałe i nie wymagało wyjaśnień. Dziś teoretyk literatury może pokusić się o zrekonstruowanie jego pola semantycznego i o próbę posłużenia się nim w przedstawieniu i wyjaśnieniu samego fenomenu pisania listów na wygnaniu.

„Nekyia”, starogreckie słowo na określenie ofiary składanej zmarłym, to tytuł jedenastej pieśni Odysei, do której zapewne w liście chciał nawiązać Wittlin. Opowiada ona o przygodach Odyseusza i jego wędrówkach po oceanie, który oddziela świat żywych od królestwa zmarłych. W poszukiwaniu ojczyzny król Itaki dociera w nocy do pograżzonej we mgle wyspy Kimmerów. Ma tam zapytać Tejrezjasza 
o swoje przeznaczenie. Zanim to nastapi, musi jednak najpierw złożyć w ofierze żywe stworzenie. Zwabione świeżą krwią duchy powoli przybywają i chcą z nim rozmawiać. Nekyia oznacza zatem przywoływanie zmarłych przez złożenie krwawej ofiary, jak również samą rozmowę $\mathrm{z}$ nimi, co niekoniecznie musi być równoznaczne z katabazą, toposem zejścia do Hadesu.

Antyczny motyw nekyi odgrywa poczesną rolę w literaturze powojennej. Tylko w samym r. 1947, kiedy Broch i Wittlin ze sobą koresponduja, ukazały się niezależnie od siebie dwa opowiadania zatytułowane Nekyia: po niemiecku i po polsku. Hans Erich Nossack (1901-1977) - laureat nagrody im. Georga Büchnera w 1961 r. oraz, podobnie jak Wittlin, członek Niemieckiej Akademii Języka i Literatury - dodał swojemu prozatorskiemu debiutowi jeszcze podtytuł: Relacja ocalonego. Tekst Nossacka powstał pod wpływem bombardowań Hamburga i ma elementy autobiograficzne. Narrator pierwszoosobowy znajduje się, jak można się domyślać, w mieście doszczętnie zniszczonym w czasie wojny - określonym jako „bezdrzewny płaskowyż w deszczu" ${ }^{34}$. Przemieszcza się po nim jak w półśnie, wspomnienia mieszają mu się $z$ jawą, „stracił wszelkie poczucie kierunku” ${ }^{35}$, wokół niego leżą ludzkie ciała niczym gliniane grudy. Bohater Nossacka nie ma imienia, składa je w ofierze na ołtarzu zapomnienia, by móc połączyć się z tymi, co odeszli.

Rozmowa $z$ duszami zmarłych to także temat opowiadania Andrzeja Bobkowskiego, które ukazało się w pierwszym numerze paryskiej „Kultury”. Bobkowski (1913-1961), polski pisarz emigracyjny, który opuścił kraj w r. 1939, jeszcze przed wybuchem wojny, najpierw wyjechał do Francji, skąd wyruszył do Gwatemali. Swoją drogą, on również wymienił kilka listów $z$ Wittlinem ${ }^{36}$. W jego utworze narratorem jest młody emigrant, paryski spacerowicz, który przypadkiem wchodzi do opuszczonego domu, gdzie ponoć kiedyś mieszkał Balzak. Doznaje tam fantastycznej wizji: spotyka duchy wielkich francuskich pisarzy. Zapach świeżych gazet w jego dłoni zwabia Balzaka, Flauberta, Le Bona, de Custine’a, Taine’a, Bainville’a i Renana. Zmarli wraz z bohaterem-narratorem wdają się w dyskusję o wydarzeniach politycznych i przyszłości Europy. Tekst kończy cytat - zdanie Odyseusza o rozpaczy w Hadesie: „Napełniły [duchy] piekło ponurymi jęki i skargami strasznymi”, które bohater Bobkowskiego, naznaczony upiornymi doświadczeniami wojny, komentuje lakoniczne: „Nie - bo ich świat nie jest już piekłem...”37.

W opowiadaniach Nossacka i Bobkowskiego nekyia stanowi okazję do literac-

H. E. N o s s a c k, Nekyia. Bericht eines Überlebenden. Frankfurt am Main 1974, s. 22.

Ibidem, s. 7.

Bobkowski z powodu swojej „podwójnej emigracji”, przez Francję do Ameryki Łacińskiej, jest porównywany z innym niemieckim pisarzem - G. Reglerem. Zob. M. Dąbrowski, D. Uffelm a n n, Kulturelle und literarische Räume doppelter Emigration (Frankreich - Lateinamerika): Andrzej Bobkowski und Gustav Regler. W zb.: Exklusion. Chronotopoi der Ausgrenzung in der russischen und polnischen Kultur des 20. Jahrhunderts. Hrsg. W. S. Kis s el, F. Thun-Hoh enstein. München 2006, s. 1. W archiwum Houghton Library zachowały się tylko 3 listy Bobkowskiego i 8 listów od jego żony Barbary, która po śmierci Bobkowskiego w 1961 r. pisała do Wittlina. W najnowszych badaniach opowiadanie Nekyia jest analizowane w kontekście „antysemickich wypowiedzi autora z początku wojny" - zob. Ł. Mi k oł a j e w s k i, Disenchanted Europeans: Polish Émigré Writers from "Kultura” and Postwar Reformulations of the West. Bern-Oxford 2018, s. 378.

A. B obkows ki, Nekyia. „Kultura” 1947, nr 1, s. 31. 
kiego przepracowania traum drugiej wojny światowej. Obraz wchodzenia w rozmowę $z$ tym, co martwe - a więc także $z$ tym, co boli, co zostało utracone, zapomniane, wyparte czy stłumione - jest doskonałą metaforą rozważań psychoanalitycznych. Carl Gustav Jung używa symbolicznego wymiaru nekyi do opisania procesu wkraczania świadomości w głębsze warstwy nieświadomej psychiki w celu przywrócenia i regeneracji pełnej osobowości ${ }^{38}$.

Naszkicowane tu tło historyczno- i teoretycznoliterackie może rzucić nowe światło na Brocha i Wittlina, w podobny sposób dałoby się rozważać nekyię w kontekście ich epistolografii. Wzmianka o tym toposie jest nie tylko aluzją do antyku jako punktu orientacyjnego w powojennym świecie. To również klucz do autorefleksji pisarzy na wygnaniu. Toposy kulturowe są integralną częścią ich języka, a właściwie metajęzyka. U reprezentantów tego pokolenia występuje on we wszystkich formach ich ekspresji, więc także w liście, który jako medium ma funkcję użytkową, dzięki zaś takim odniesieniom zyskuje też wymiar artystyczny.

Żeby prowadzić ożywioną korespondencję, trzeba poświęcić na to wiele czasu. Paradoksalnie jednak - bez tej przerwy w pracy twórczej, przerwy na... pisanie listów, omawiani autorzy nie radzą sobie. W listach bowiem mogą swobodnie ponarzekać na przemęczenie i na chroniczny brak czasu. Broch wysyła Wittlinowi 3 III 1950 pocztówkę (po angielsku) o następującej treści: „Jak się masz, drogi przyjacielu? Już za długo nie słyszałem od Ciebie ani słowa. U mnie zawsze to samo: powolne samobójstwo z wyczerpania. "Pourvu que ça dure!"” (wyrażenie francuskie, oznaczające „I niech tak zostanie” - to słowa Letizii Bonaparte, matki cesarza, o zwycięstwach jej syna). Chociaż obaj są zajęci, chcą pozostać w kontakcie i nawzajem prowokują dalszą wymianę wiadomości. Poświęcają swoją energię i czas, w ten sposób w pewnym sensie wskrzeszając bądź wywołując niczym duchy „umarłą” i „anachroniczną” formę listu. Tak właśnie określił ją Theodor W. Adorno w eseju z 1966 r. o Walterze Benjaminie jako epistolografie ${ }^{39}$. Według Adorna pisanie listów „w epoce rozpadu doświadczenia” zdezaktualizowało się, ponieważ tą czynnością indywiduum rości sobie prawo do bycia kimś, kim już dawno nie jest lub nie może już być - do postrzegania siebie jako złożonej całości i „nieodgadnionej jednostki” 40 .

Broch i Wittlin zdają się obalać tezę Adorna i dlatego ich korespondencja może być inspirująca nie tylko dla badań porównawczych literatury emigracyjnej, ale także dla rozważań teoretycznych nad epistolografią. Nie piszą oni bowiem do siebie w stylu minionych epok, kiedy to jeszcze list odgrywał - jak mówią dziś historycy - istotną rolę w „rozwoju sentymentalnego systemu wartości mieszczaństwa” czy też w „powstaniu i inscenizacji podmiotowości estetycznej”41. Szczególnie w oświeceniu list był uważany za symbol bądź organ europejskiej kultury uczonych, którą Krzysztof Pomian zwykł nazywać „République des lettres”. Pod tym pojęciem rozumie on ideał ówczesnej sfery publicznej złożonej z wolnych i równych uczonych

41 J. Schus ter, „Kunstleben”: Zur Kulturpoetik des Briefs um 1900 - Korrespondenzen Hugo von Hofmannsthals und Rainer Maria Rilkes. Paderborn 2014, s. 14-15. 
i pisarzy, później nazwanych intelektualistami, którzy komunikowali się poprzez listy, często otwarte, oraz przez czasopisma, w ten sposób wymieniając ze soba pomysły na poprawę świata ${ }^{42}$. Trudno się wobec tego dziwić, że Adorno łączy list z koncepcja silnego, pewnego siebie podmiotu.

Ten krótki rys teorii i historii epistolografii tłumaczy, dlaczego Broch i Wittlin wyłamują się z tej tradycji. Chociaż nadal posługują się medium listu, to nie wierzą już w jego oświeceniowy potencjał naprawy świata i samostanowienia podmiotu. Doskonale wiedzą, że procesu rozpadu wartości nie da się już ani odwrócić, ani zatrzymać. Dlatego próbują zmierzyć się z tym tematem literacko i umieszczają go w centrum swojej prozy. Ale wyraźnie przenika on także do ich korespondencji pisanej w sytuacji wypędzenia - dosłownego i metaforycznego, pojętego jako bycie nie $\mathrm{u}$ siebie $\mathrm{w}$ domu, wykorzenienie i niedopasowanie do norm i schematów obowiązujących w obcym świecie. Uchodźstwo jest niczym czyściec, stan zawieszenia, przebywania pomiędzy żywymi a martwymi. Albo inaczej, w bardziej „laickim” rozumieniu - niczym nowoczesność par excellence. Listy Wittlina i Brocha można więc interpretować jako rodzaj nekyi - utylitarną formę komunikacji, już archaiczną, ale na nowo ożywiona po to, by móc wejść w kontakt $z$ drugim człowiekiem i uratować indywidualne doświadczenie, wyparte przez nieludzką historię nowoczesnego rozumu. $\mathrm{W}$ tym medium pisarze odnajduja miejsce na autotematyzm i intertekstualną ironię. List nie jest już dla nich narzędziem zmiany świata, lecz jedynie schronieniem dla „poharatanego życia” 43 - dla bezbronnego, zranionego, naznaczonego traumami indywiduum.

\section{Emigranci}

W korespondencji Brocha i Wittlina dominuja przede wszystkim obrazy gorzkich i upokarzających doświadczeń życia na emigracji, takich jak np. trudna sytuacja finansowa czy niepewność egzystencjalna. Wittlin dość długo boryka się z myślą o powrocie do Polski - pisze:

co prawda nie będę [tam] miał pełnej wolności, ale [...] również nie będę miał upokarzających trosk i idiotycznych prac do wykonania, które tutaj całkowicie wypełniają mi życie, nie dając przy tym żadnej opportunity [nowej możliwości]. [list z 28 VII 1947]

Broch zdecydowanie mu ten pomysł odradza i twierdzi, że obecna sytuacja polityczna to najmniej odpowiedni moment do takich podróży (28 IX 1948). Stara się pomóc Wittlinowi, gdy ten w 1947 r. ubiega się o stypendium Guggenheima, przygotowuje wówczas dla niego list rekomendacyjny pełen pochwał. Gorąco popiera w nim „projekt życiowy” Wittlina: jego marzenie, aby napisać, czy też raczej zrekonstruować dwa kolejne tomy - kontynuację powieści Sól ziemi. Według relacji polskiego pisarza manuskrypty z gotowymi rozdziałami kolejnych części zaginęły

42 K. P o m i a n, République des lettres - jej wrogowie i sojusznicy. W: Przeszłość jako przedmiot wiedzy. Warszawa 1992, s. 159.

43 Th. W. Ad or n o, Minima moralia. Refleksje z poharatanego życia. Przekł., przypisy M. Łu ka si ewicz. Posł. M. J. Si emek. Wyd. 2. Kraków 2009. 


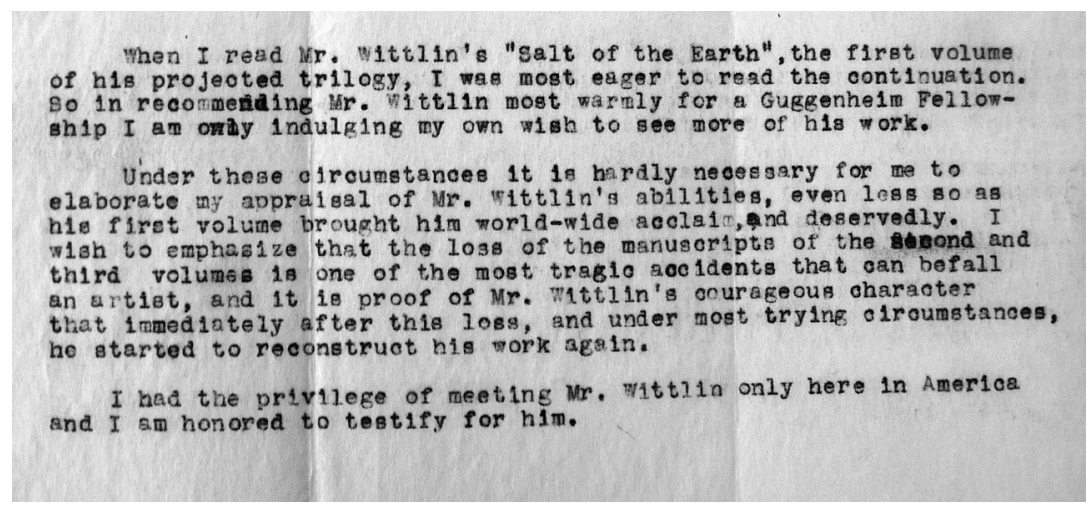

2. Odpis listu rekomendacyjnego Brocha dla Wittlina

we Francji pod koniec czerwca 1940, w trakcie jego ucieczki. Planu ukończenia trylogii Wittlin, niestety, nigdy nie zrealizował, dlatego w listach do Brocha ironicznie nazywał siebie „polskim Lucjuszem Wariuszem”, w nawiązaniu do starorzymskiego poety, którego dzieła również się nie zachowały.

Krótka uwaga na marginesie: kilka lat później Wittlin został poproszony o tę sama przysługę - w 1969 r. napisał do fundacji Guggenheima opinię dla swojego młodszego kolegi literata, także przebywającego na emigracji - Henryka Grynberga (ur. 1936). Niestety, jemu również nie udało się zdobyć tego wyróżnienia, konkurs był jednak dobra okazją, by się ze sobą skontaktowali. Grynberga i Wittlina zdaje się wiele łączyć, np. zainteresowanie Galicją i historią relacji polsko-żydowskich. Grynberg był zachwycony książką Wittlina Mój Lwów, w jednym z pisanych do niego niedatowanych listów, najprawdopodobniej z początku lat siedemdziesiątych, określa się sam mianem „fanatycznego wittlinisty” i żartobliwie adresuje pocztówkę do niego na „Lwów (koło Nowego Jorku)”.

Brak środków do życia, poczucia bezpieczeństwa i czasu na pracę literacka to znane toposy w korespondencji wszystkich pisarzy mieszkających na obczyźnie także w listach Brocha i Wittlina dochodzą one bardzo wyraźnie do głosu. Powage i skalę tych problemów świetnie puentuje lekko sarkastyczny komentarz, który pojawia się $\mathrm{w}$ korespondencji innych polskich pisarzy emigracyjnych, również przechowywanej w archiwum Beinecke: Melchior Wańkowicz w jednym $z$ listów do Miłosza stwierdza mianowicie, że przedstawia on swoją sytuację w Stanach Zjednoczonych jeszcze gorzej niż tę za niemieckiej okupacji w czasie drugiej wojny światowej. Podobny, niemal tragiczny ton wypowiedzi można zaobserwować w wymianie zdań między Wittlinem a Brochem. Obaj jednak starają się nawzajem wspierać czy nawet - powiedzielibyśmy, używając modnego dzisiaj wyrażenia prowadzą pewnego rodzaju obopólny coaching. Wittlin konsekwentnie pyta Brocha o jego postępy w pracy, Broch natomiast poleca Wittlinowi, aby spróbował nauczać literatury i historii polskiej na uniwersytetach - przedstawia mu np. pomysł, żeby założył Polski Dom Literatury w ramach New School for Social Research w Nowym Jorku, co miałoby duże szanse powodzenia, jeśli weźmie się pod uwagę liczną polsko-żydowską emigrację na Brooklynie. Przy okazji Broch opowiada Wittlinowi, jak 


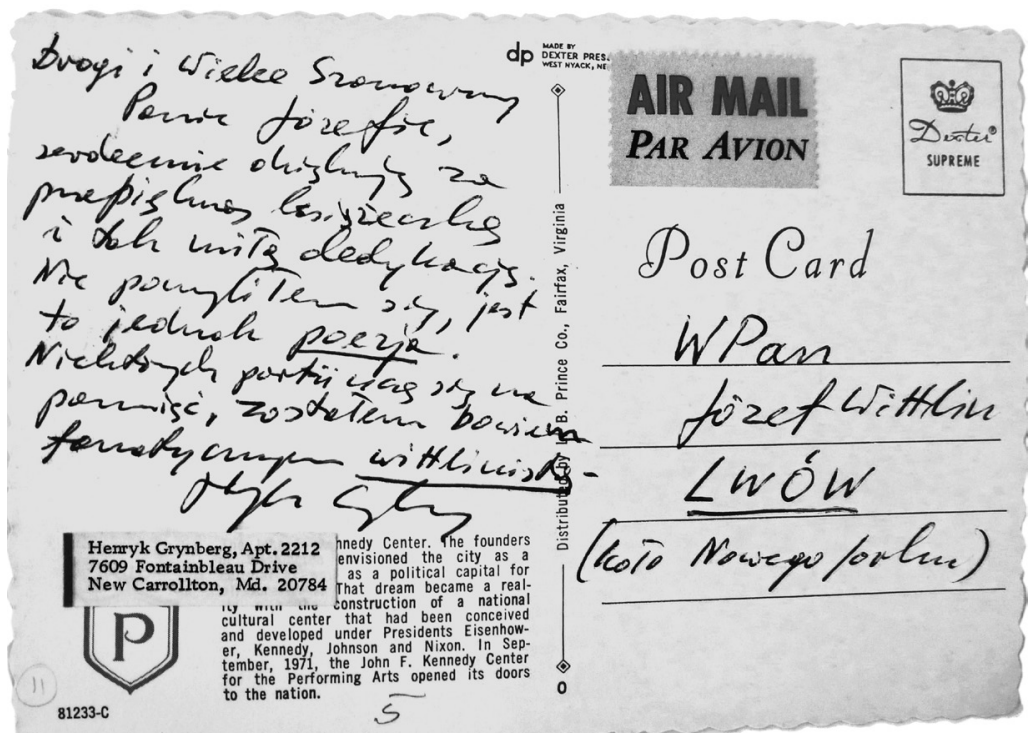

3. Pocztówka Grynberga do Wittlina (rewers)

udało mu się zdobyć profesurę gościnną na Uniwersytecie Yale i na czym polegają jego zadania:

Moją pozycję tutaj określiłbym jako porównywalną ze zwierzęciem w menażerii i tak też jest ona opłacana, tzn. bez pieniędzy, tylko klatka, siano i wyżywienie. W zamian nie mam żadnych innych zobowiązań, jak tylko dać się oglądać. [...] Moje obowiązki ograniczają się do kontaktów socjalnych, czyli do bycia dystyngowanym gościem, i mogę Pana zapewnić, że jest to czasem okropnie uciążliwe. Nie jest to lekko zarobiony chleb, jednak, biorąc pod uwagę moją sytuację finansową, powinienem się cieszyć, że mam taką pracę. [5 VI 1949]

Broch próbuje nawet zaprosić Wittlina do New Haven na wykład gościnny poprzez skontaktowanie go z prof. Heinzem Blumem, przewodniczącym Germanic Club na Uniwersytecie Yale. Autor Lunatyków sugeruje Wittlinowi, by przygotował referat poświęcony porównaniu rozwoju literatury polskiej i niemieckiej. W listach mowa jest o praktycznych szczegółach, np. Broch ubolewa nad „mizerną zapłata” (5 VI 1949). Nie sposób potwierdzić, czy wykład Wittlina się odbył. Sytuacja finansowa pisarza poprawiła się dopiero w latach pięćdziesiątych, kiedy otrzymał on prace w rozgłośni Radia Wolna Europa w Nowym Jorku.

\section{Pisarze przetransplantowani}

Kolejnym motywem, który powtarza się w korespondencji obu pisarzy, jest nostalgia i tęsknota za Europą. Broch, wspominając w jednym $z$ listów o swojej pracy nad esejem o Hugonie von Hofmannsthalu, zauważa, że nadal kocha Austrię swojej młodości miłością „niemal żałobną” (21 X 1948). Razem z Wittlinem planują wspólną podróż nad Morze Śródziemne lub - jak to ujmuje Broch - „ins Humanere [do miejsc bardziej przyjaznych ludziom]” bądź „gdziekolwiek tam, gdzie leżą 


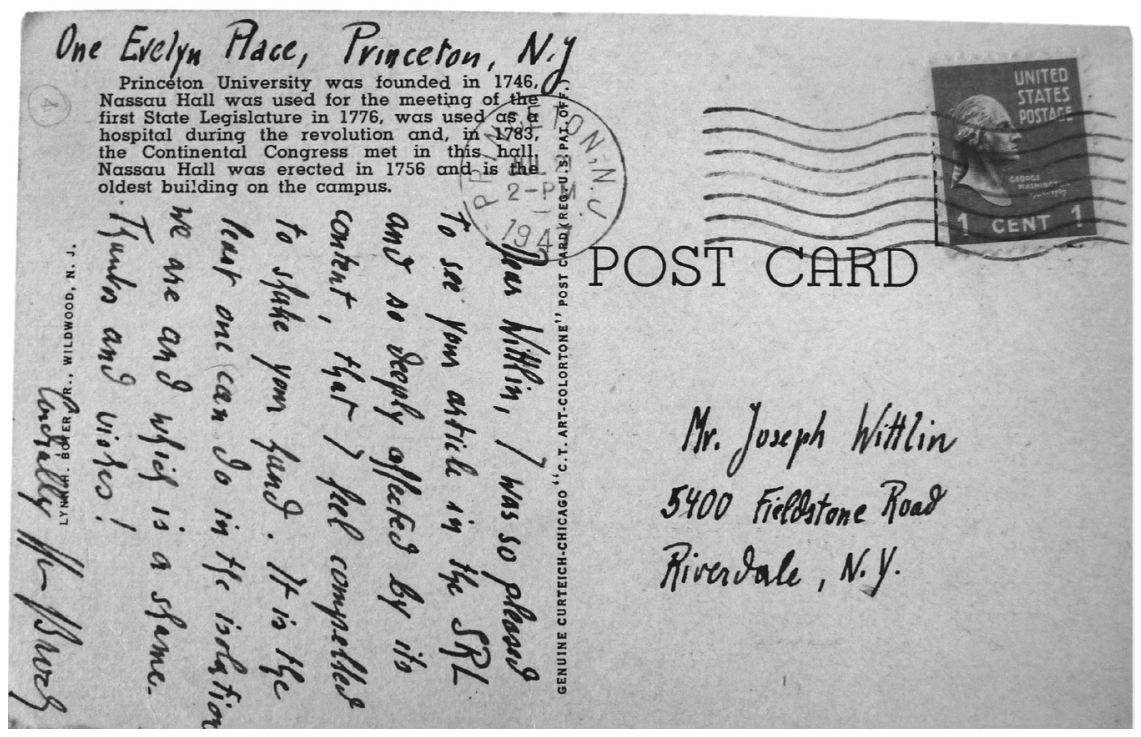

4. Pocztówka Brocha do Wittlina (rewers)

stare kamienie, których można dotknąć niczym Anteusz" (1 I 1949). Odniesienie do mitycznego giganta, który w trakcie walk miał czerpać nowe siły dzięki dotknięciu ziemi i który został przechytrzony przez Heraklesa, nie jest tu bez znaczenia. W listach często wspomina się o „Anteuszowym nastawieniu, jakie mamy w stosunku do Europy" (list Brocha do Wittlina, z 5 VI 1949). Plany wyjazdu stają się coraz bardziej konkretne - pisarze chcą wiosna 1950 zamieszkać razem przez kilka miesięcy na południu Francji. Broch podkreśla, że ta propozycja ma nie tylko charakter retoryczny: „I mean it [Mówię poważnie], tym bardziej że możemy zaoszczędzić mnóstwo pieniędzy, jeżeli zostaniemy tam odpowiednio długo, aż zwrócą się nam koszty podróży” (10 V 1949). To jednak okres trudny pod względem finansowym dla Wittlina, chciałby on wyjechać, ale nie stać go na to. Odpisuje Brochowi:

Na moje stare lata stałem się w końcu realistą i I realise [zdaję sobie sprawę], że jestem tylko biednym, zagubionym człowiekiem, który musi ciężko pracować, podejmując się głupich zajęć, żeby utrzymać siebie i rodzinę. [30 V 1949]

Do ważnych tematów często pojawiających się w tej wymianie listów należą również duchowe wyobcowanie na emigracji i ograniczone kontakty, głównie $z$ intelektualistami ze środowisk uchodźców z Europy. Kiedy Broch przeczytał artykuł Wittlina The Perception of Hell w czasopiśmie literackim „Saturday Review of Literature" 44 , nie zwlekał $\mathrm{z}$ wysłaniem koledze pocztówki $\mathrm{z}$ gratulacjami, wyjątkowo w języku angielskim: 
Bardzo się ucieszyłem, kiedy zobaczyłem Pański tekst w SRL, jego treść tak bardzo mnie poruszyła, że czuję się zobowiązany, by uścisnąc Pana dłoń. To jedyne, co możemy zrobić, żyjąc w tej haniebnej izolacji. [21 VII 1947]

Żaden $\mathrm{z}$ nich nie potrafi do końca zadomowić się w Stanach Zjednoczonych. Mają liczne problemy zdrowotne, które opisują sobie ze szczegółami. W liście z 20 VIII 1945 Broch notuje: „Podobnie jak Pan, coraz wyraźniej odczuwam emigrację i aklimatyzację. Obydwie sprawy pochłaniają, niestety, dużo energii i zdrowia”. Kiedy indziej stwierdza:

Pewnie zabrzmi to paradoksalnie, ale im dłużej mieszkam w tym kraju, tym trudniej przychodzi mi aklimatyzacja. Albo, precyzując myśl, im jestem starszy, tym wyraźniej widzę, że nadal się nie zaaklimatyzowałem. Tak samo może być w Pana przypadku. [5 VI 1949]

Czasami ironicznie wypowiadają się o swoim stanie zdrowia; obaj cierpią na podobne choroby muszą poddawać się operacjom i mają za sobą pobyty w szpitalach, Broch również jeden dłuższy z powodu złamania biodra w 1949 roku. Obaj zapowiadają, że będą się nawzajem odwiedzać w chorobie; Broch nazywa siebie i Wittlina „przypadkami paralelnymi” (5 VI 1949), nawet upomina żartobliwie kolegę, by ten go nie naśladował i nie miał „niezdrowych ambicji” (6 VII 1948), jeśli chodzi o konkurencję w dziedzinie chorowania.

Oprócz zwykłych narzekań w listach pojawia się także wątek subtelnej krytyki i dyskredytacji amerykańskiej kultury masowej. „Zwłaszcza w tym kraju” - zauważa Wittlin w swoim pierwszym liście do Brocha - „szybko można się przyzwyczaić do banałów”. Sytuacja życia na obczyźnie, na nowym kontynencie, zmusza obu korespondentów do refleksji nad tym, czym są cywilizacja, tradycja i dziedzictwo kulturowe. Te wartości zgodnie przypisuja oni Staremu Lądowi - Europie. Broch stwierdza np.:

Wydaje mi się, że najtrudniejszy etap aklimatyzacji stanowi przystosowanie się do braku historii; proszę sobie tylko przeliczyć, jak mało ludzi leży pochowanych w północnoamerykańskiej ziemi: życie tutaj jest męczące. [1 I 1949]

Dlatego obaj często odwołują się do antycznych korzeni europejskiej kultury wysokiej. Aluzje do starożytnej Grecji i Rzymu - do mitologii, literatury i sztuki tworzą ich wspólny kod komunikacyjny. Obaj cierpią na tę samą chorobę co inni im współcześni europejscy „mandaryni”.

Treść listów między Brochem a Wittlinem jest w wielu miejscach mało oryginalna i potwierdza tylko znany schemat narracyjny europejskich intelektualistów, którzy wyemigrowali $z$ Europy do Stanów Zjednoczonych w latach trzydziestych lub czterdziestych XX wieku. Te reakcje oraz zachowania, np. Thomasa i Heinricha Mannów czy Bertolta Brechta, zostały doskonale sportretowane w sztuce teatralnej Opowieści Hollywoodu (1984) Christophera Hamptona. Podobny los przypisuje się także Adornowi i Maxowi Horkheimerowi: mieszkając na przedmieściach Los Angeles, mieli oni deliberować o szkodliwych skutkach przemysłu rozrywkowego niby to zupełnie obojętni czy nawet czujący wyższość wobec niego, mentalnie za-

nym w Sztokholmie czasopiśmie literackim „Neue Rundschau”, we wspomnianym już specjalnym numerze $\mathrm{z}$ okazji siedemdziesiątych urodzin Manna, później ukazała się jako esej pt. Pochwała fikcji poetyckiej w książce Orfeusz w piekle XX wieku. 
mknięci w europejskiej „wieży z kości słoniowej”. Skądinąd warto zauważyć, że ten stereotyp niezaangażowanego emigranta-obserwatora, który pozostaje niewzruszony i nie ulega wpływom nowego miejsca, jest ostatnio kwestionowany w badaniach historycznoliterackich, chociażby autorstwa Willa Normana ${ }^{45}$. W swej książce analizuje on przypadki m.in. Adorna, George'a Grosza czy Vladimira Nabokova i wykazuje, jak doświadczenia amerykańskie przenikały do ich praktyk estetycznych i intelektualnych oraz - vice versa - jak oddziaływali oni na kulturę w Stanach Zjednoczonych.

W swoich listach Broch i Wittlin również stylizują się na takich „transatlantyckich obcych”, chociaż nie do końca chcą się z nimi utożsamiać. W rzeczywistości obaj pisarze dobrze sie zaaklimatyzowali w Stanach Zjednoczonych. Zwłaszcza $\mathrm{w}$ badaniach nad Brochem wskazuje się na wysoki stopień jego integracji z tamtejszym środowiskiem. Aktywnie uczestniczył on w wielu inicjatywach, takich jak grupa City of Man, w której skład wchodzili intelektualiści niemieccy i amerykańscy, oraz angażował się w publikacje manifestów na rzecz demokracji. Literaturoznawca Daniel Weidner zauważa, że Broch od dnia przybycia do Nowego Jorku, 10 X 1938, był od rana do wieczora zajęty licznymi spotkaniami ${ }^{46}$. Zdaniem Weidnera, jego pobyt w Stanach Zjednoczonych nie oznacza izolacji, a ekscesywna korespondencja, pokonująca odległości i tworząca sieci kontaktów, jest tego dobitnym potwierdzeniem ${ }^{47}$. Również Wittlin w jednym ze swoich artykułów, Transplanted Writers (Pisarze przetransplantowani), zastanawia się nad emigracja jako sytuacją obustronnej wymiany kulturowej:

Amerykanie mogą czerpać $\mathrm{z}$ wieloletniego doświadczenia Europejczyków, zarówno jeśli chodzi o metodę, jak i o technikę definiowania procesu myślowego. $Z$ drugiej strony, Europejczycy moga w Ameryce nieco odświeżyć swoje zmęczone wyobrażenia; mogą wyzwolić się z rutyny, która czasami zajmuje miejsce tradycji; mogą odmłodzić swój wzrok, często wyczerpany nieustanną koncentracją na pojedynczym punkcie; i mogą przyjąć to szerokie spojrzenie, które charakteryzuje amerykańską kreatywność od czasów Walta Whitmana ${ }^{48}$.

To celne sformułowanie trzeba odnieść do samego autora i do Brocha: obaj próbuja postrzegać siebie jako „pisarzy przetransplantowanych”, a więc jako żywe organy w nowym organizmie społeczno-kulturowym, jako otwarte podmioty w stałej interakcji $z$ amerykańską rzeczywistością.

\section{Niedokończone historie}

Omawiana korespondencja Wittlina i Brocha zachęca do przemyśleń w trybie „co by było, gdyby..." - do snucia historii alternatywnych, przypuszczeń i wyobrażeń na

46 Hermann Broch and the Ethics of Exile. W zb.: „Escape to Life”. German Intellectuals in New York: A compendium on Exile after 1933. Ed. E. Go e b el, S. W ei gel. Berlin-Boston 2012, s. 164.

W. N o r m a n, Transatlantic Aliens. Modernism, Exile and Culture in Midcentury America. Baltimore 2016.

D. W e i d n e r, „Without knowing America, you cannot say anything valid about democratic politics”. D. W e i d n e r, Neither here nor there - Hermann Broch's Writing in Exile. Transl. T. B o y d. „Yearbook for European Jewish Literature Studies” 2015, z. 1, s. 175.

J. W ittli n, Transplanted Writers. (A Symposium, Continued). „Books Abroad” 1942, z. 4, s. 385. 


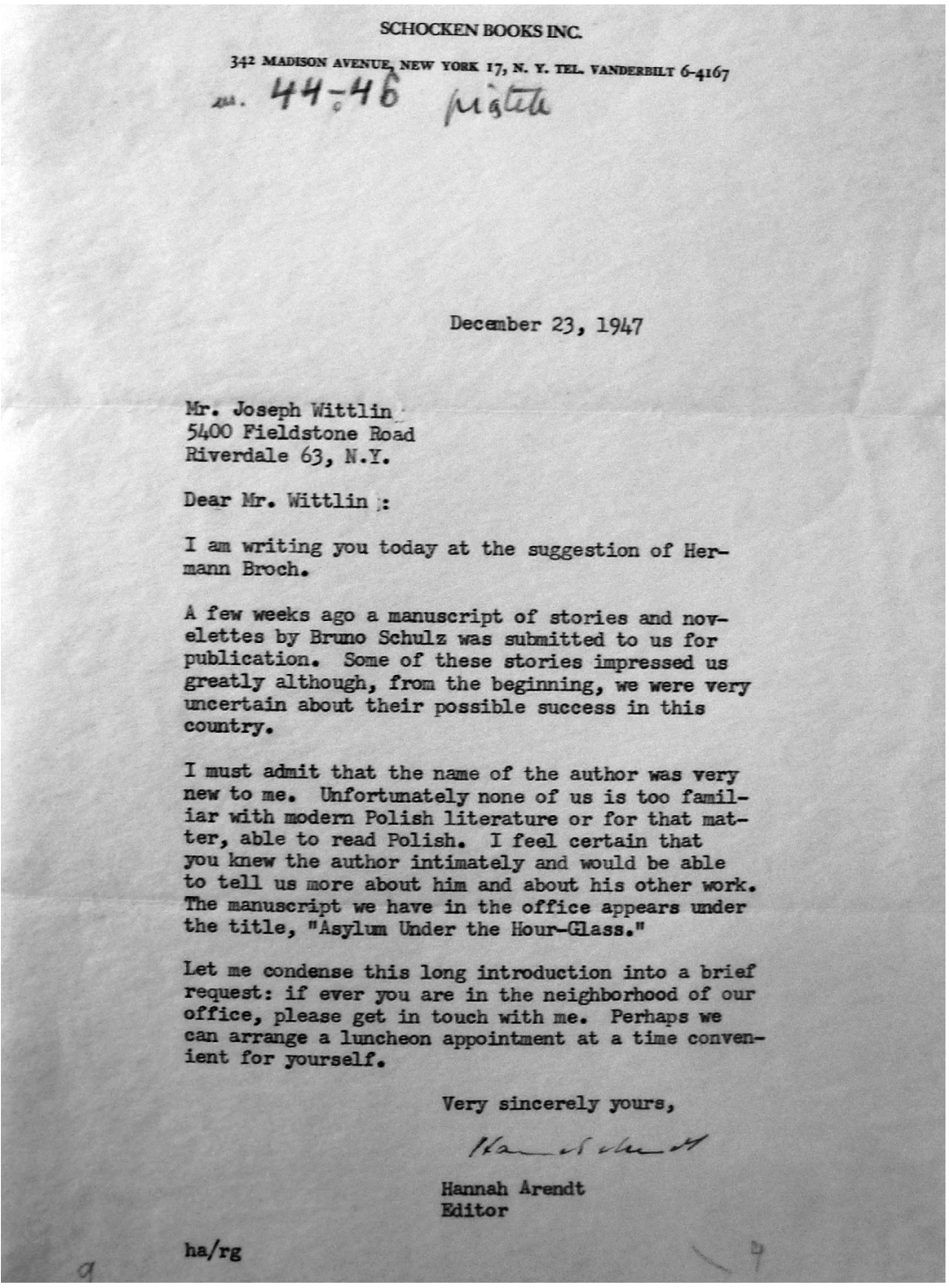

5. Pismo Arendt do Wittlina

temat tego, jak obaj pisarze mogliby jeszcze intensywniej ingerować w życie literackie i artystyczne. Dwa przykłady: 23 XII 1947 Hannah Arendt wysłała list do Wittlina - na polecenie Brocha, jak wyjaśniła w pierwszych zdaniach. Jako redaktorka zatrudniona w wydawnictwie „Schocken Books”, które publikuje dzieła takich autorów, jak Walter Benjamin, Franz Kafka czy Gershom Scholem, chciałaby zasięgnąć porady Wittlina. Jakiś czas temu otrzymała manuskrypt z tłumaczeniem opowiadań niejakiego Brunona Schulza. Asylum Under the Hour-Glass, tak brzmi roboczy tytuł przekładu. Nikt z jej otoczenia nie zna się na literaturze polskiej, dlatego zwraca się 
ona do Wittlina z prośbą o spotkanie - chce dowiedzieć się więcej o tajemniczym pisarzu z Drohobycza. Wittlin, który m.in. poświęcił wiersz jednej z Schulzowskich postaci $^{49}$, jest w tym zakresie bardzo kompetentnym źródłem informacji. Niestety, trudno potwierdzić, czy doszło do rozmowy Arendt $z$ Wittlinem. Niemniej już samo wyobrażenie sobie takiej historii alternatywnej wydaje się fascynujące: co by było, gdyby Wittlin przekonał Arendt do tej publikacji i pierwsze angielskie tłumaczenie Schulza ukazało się wówczas, a nie dopiero wiele lat później? ${ }^{50}$ Jak wyglądałaby dzisiejsza światowa recepcja Schulza i kogo by zainspirowała jego twórczość?

Wielki potencjał pobudzania do spekulacji i do snucia domysłów ma również inna konstelacja osobowa, utworzona przez obu pisarzy. Ostatnie znajdujące się w archiwum świadectwo ich kontaktów to krótka wiadomość, którą Broch wysłał na początku stycznia $1951 \mathrm{z}$ informacją, że Wittlin niebawem powinien otrzymać egzemplarz jego najnowszej powieści Niewinni. W liście do Gombrowicza, z 16 II 1951, Wittlin, który uchodził za zaufanego doradcę autora Ferdydurke w sprawach jego początkującej kariery literackiej poza granicami kraju, oznajmia, że właśnie dziś wspomniał o nim pochwalnie w liście do Brocha i obiecał mu przesłanie francuskiego przekładu sztuki teatralnej Ślub ${ }^{51}$. Przy okazji wyjaśnia, że od dawna jest zaprzyjaźniony z Brochem, że uważa go za jeden z największych pisarskich autorytetów i że jego kontakty wydawnicze mogą być pomocne. Gombrowicz natychmiast odpowiada (26 II 1951) z Buenos Aires, że czytał po hiszpańsku Śmierć Wergilego. Siebie widzi raczej jako przeciwieństwo Brocha, choć jego powieść stanowi, zdaniem Gombrowicza, z pewnością dzieło monumentalne. Pisarz prosi o adres Brocha i ma zamiar wysłać mu w marcu lub kwietniu paczkę do New Haven. Nie wiadomo, czy przesyłka owa dotarła do adresata - Broch zmarł w maju tego samego roku. Pytanie, co by było, gdyby Broch otrzymał książkę, pozostawia dużo pola do fantazjowania. Czy Broch zachwyciłby się Gombrowiczem i poleciłby go swoim wydawcom? Czy Ślub mógłby zostać wkrótce wystawiony na Broadwayu? Tyle niedokończonych historii, które Broch i Wittlin mogliby wspólnie napisać...

Abstract

AGNIESZKA HUDZIK University of Potsdam

ORCID: 0000-0001-7454-7752

WAR, EMIGRATION AND THE SOUL OF THE POET ON HERMANN BROCH AND JÓZEF WITTLIN'S CORRESPONDENCE

The article treats of two writers, Hermann Broch (1886-1951) and Józef Wittlin (1896-1976), who are linked by the generational experience of the World War I. Both of them struggled with the problem of

J. Wittlin napisał o Annie Csillag wiersz À la recherche du temps perdu, którego pierwodruk ukazał się w „Wiadomościach Literackich” (1933, nr 55 〈24 XII〉, s. 13).

Angielskie tłumaczenie Sklepów cynamonowych B. S c h u lza, pod zmienionym tytułem The Street of Crocodiles (Transl. C. Wi eniews ka. New York), wydano dopiero w r. 1963, a tom drugi: Sanatorium under the Sign of the Hourglass, w 1977 roku. O recepcji Schulza w świecie anglosaskim zob. B. R. B a nks, Poza granicami: Bruno Schulz w języku angielskim. Przeł. M. Ma ry 1. „Teksty Drugie” 2008, nr 6.

Gombrowicz, Wittlin, Iwaszkiewicz, Sandauer, op. cit., s. 21-29, 38, 40. 
representation of the war in their seminal works Die Schlafwandler (Sleepwalkers) and Sól ziemi (Salt of the Earth). The similarities between the novels' protagonists form the starting point to an attempt at comparing the authors' biographies and their literary outputs. The sketch was produced as based on source text search query of so far unpublished German correspondence between Broch and Wittlin kept up between 1945-1951. The letters are preserved in two literary archives Beinecke Rare Book \& Manuscript Library (Yale, New Haven) and Houghton Library (Harvard, Cambridge). 